\title{
PENGARUH PENGGUNAAN MATA PANCING GANDA PADA RAWAI TEGAK TERHADAP HASIL TANGKAPAN LAYUR
}

\author{
Regi Fiji Anggawangsa'), Bambang Murdiyanto2), dan Wudianto1) \\ 1) Peneliti pada Pusat Riset Perikanan Tangkap, Ancol-Jakarta \\ 2) Dosen pada Fakultas Perikanan dan IImu Kelautan, Institut Pertanian Bogor, Bogor \\ Teregistrasi I tanggal: 25 Juni 2009; Diterima setelah perbaikan tanggal: 6 Juli 2009; \\ Disetujui terbit tanggal: 16 Juli 2009
}

\begin{abstract}
ABSTRAK
Rawai tegak merupakan salah satu alat penangkap ikan yang digunakan nelayan untuk menangkap ikan layur (Trichiurus sp.). Pengembangan metode dan teknologi dalam unit penangkapan rawai tegak ini sangat diperlukan untuk meningkatkan hasil tangkapan, salah satunya adalah dengan modifikasi mata pancing. Mata pancing yang digunakan nelayan rawai tegak adalah mata pancing tunggal. Selain mata pancing tunggal terdapat juga berbagai jenis mata pancing, salah satunya adalah mata pancing ganda yang dipasang berangkai. Penelitian ini dilakukan di perairan Pelabuhanratu, Jawa Barat dengan menggunakan dua jenis rawai sebagai perlakuan yaitu rawai yang menggunakan mata pancing tunggal dan rawai yang menggunakan mata pancing ganda yang dipasang berangkai. Kedua rawai tersebut terdiri atas 10 tali cabang yang diujungnya terdapat mata pancing. Mata pancing yang digunakan adalah mata pancing No.9 untuk mata pancing tunggal dan No.9 dan 12 untuk mata pancing ganda. Berdasarkan pada hasil uji peringkat bertanda Wilcoxon didapatkan perbedaan yang nyata antara hasil tangkapan rawai yang menggunakan mata pancing tunggal dan rawai yang menggunakan mata pancing ganda. Rawai yang menggunakan mata pancing ganda menghasilkan hasil tangkapan yang lebih baik dibandingkan rawai yang menggunakan mata pancing tunggal.
\end{abstract}

\section{KATAKUNCI: mata pancing, rawai, ikan layur}

\section{PENDAHULUAN}

Ikan layur (Trichiurus sp.) merupakan salah satu komoditas perikanan yang potensial di Indonesia. Dalam beberapa tahun terakhir ikan layur menjadi salah satu komoditas perikanan yang penting, hal ini dapat dilihat dari nilai produksinya yang semakin bertambah dari tahun ke tahun dan meningkatnya permintaan ekspor ikan layur ke beberapa negara Asia seperti Korea Selatan, Jepang, Cina, Hongkong, dan Taiwan. Ikan layur merupakan jenis ikan demersal yang tersebar hampir di seluruh perairan pantai di Indonesia dengan daerah penyebaran dari perairan Teluk Benggala, Teluk Siam, sepanjang pantai Laut Cina Selatan, Filipina sampai ke pantai utara Australia (Direktorat Jenderal Perikanan, 1998).

Salah satu sentra produksi ikan layur di Indonesia khususnya di Jawa Barat adalah di Pelabuhanratu, hal ini dapat dilihat dari produksi tahunannya yang mencapai 222,6 ton dengan nilai produksi lebih dari Rp. 1,3 milyar pada tahun 2006 dan dalam beberapa tahun terakhir terjadi peningkatan jumlah produksinya (Pelabuhan Perikanan Nusantara Pelabuhanratu, 2006). Ikan layur terdapat sepanjang tahun di Pelabuhanratu, namun musim penangkapan ikan layur terjadi satu kali dalam satu tahun, yaitu antara bulan Oktober-Januari dengan puncaknya terjadi bulan Nopember, sedangkan hasil tangkapan terendah tercatat pada bulan Mei. Kelimpahan tertinggi terjadi antara bulan Oktober-Januari yang bertepatan dengan awal dari musim barat. Ikan layur tidak seperti ikanikan pelagis yang pada umumnya saat musim barat kelimpahannya menurun (Sasmita, 1995).

Alat tangkap yang digunakan untuk menangkap ikan layur antara lain pancing, gill net, payang, dan bagan. Pada umumnya nelayan menggunakan pancing ulur atau rawai untuk menangkap ikan layur. Pancing ulur adalah pancing yang menggunakan satu mata pancing sedangkan rawai menggunakan lebih dari satu mata pancing yang dipasang dengan tali cabang (branch line). Menurut Sadhori (1984), rawai dapat diartikan sebagai salah satu alat penangkapan ikan yang terdiri atas rangkaian tali-temali yang bercabang-cabang dan pada tiap-tiap ujung cabangnya diikatkan sebuah mata pancing. Berdasarkan pada susunan mata pancing pada tali utamanya, rawai dapat dibedakan menjadi rawai tegak (vertical longline), rawai mendatar (horizontal longline), dan pancing landung.

Mata pancing (hook) merupakan bagian yang sangat penting dalam proses penangkapan ikan layur, karena ikan layur akan terkait pada mata pancing tersebut. Pada umumnya mata pancing yang digunakan nelayan pancing ulur maupun rawai di Pelabuhanratu hanya bermata pancing tunggal dan 
pada kenyataannya tinggkat keberhasilannya kurang optimal karena sering kali umpan sudah tergigit atau termakan tetapi ikan tidak terkait pada mata pancing. Selain pancing yang menggunakan satu mata pancing, terdapat pula yang menggunakan dua atau lebih mata pancing yang dipasang berangkai. Pancing ulur dengan dua mata pancing yang dipasang berangkai sudah banyak digunakan nelayan Belitung untuk menangkap ikan tenggiri (Scomberomerous sp.) dan hasilnya cukup memuaskan (Budiman, 2006). Penelitian ini bertujuan untuk mengetahui perbedaan hasil tangkapan ikan layur yang diperoleh dari rawai tegak yang menggunakan mata pancing tunggal dengan rawai tegak yang menggunakan mata pancing ganda. Dari hasil penelitian ini diharapkan dapat menjadi alternatif pengembangan teknologi alat tangkap ikan layur di Indonesia.

\section{BAHAN DAN METODE}

Penelitian ini dilaksanakan pada bulan Nopember 2007 di perairan Tunjangan, Teluk Pelabuhanratu, Kabupaten Sukabumi, Jawa Barat (Gambar 1). Metode yang digunakan adalah metode experimental fishing yaitu dengan melakukan operasi penangkapan langsung di lapangan.

Dalam penelitian ini digunakan dua unit alat tangkap rawai ikan layur vertikal dengan spesifikasi yang sama hanya berbeda pada mata pancingnya
(Gambar 2). Secara rinci, deskripsi rawai tegak ikan layur sebagai berikut:

1. Penggulung (reel) yang terbuat dari plastik berdiameter $20 \mathrm{~cm}$.

2. Tali utama (main line) dari bahan PA monofilament No.1.000 dengan panjang $200 \mathrm{~m}$.

3. Tali cabang (branch line) dari bahan PA monofilament No.500 dengan panjang masingmasing 1,3 m.

4. Barlen yang terbuat dari kawat baja dengan panjang $15 \mathrm{~cm}$.

5. Pemberat dari batu.

6. Swivelyang dipasang pada setiap tali cabang.

7. Mata pancing berukuran No.9 dan 12.

Kedua rawai ikan layur tersebut dianggap sebagai perlakuan, satu unit menggunakan mata pancing tunggal dan satu unit lainnya menggunakan mata pancing ganda. Mata pancing yang digunakan yaitu mata pancing No.9 untuk rawai ikan layur yang menggunakan mata pancing tunggal dan No.9 dan 12 untuk rawai ikan layur yang menggunakan mata pancing ganda dan dipasang berangkai. Masingmasing unit rawai terdiri atas 10 branch line. Uji coba kedua tipe rawai tegak dilakukan secara bersamaan 30 kali setting yang sekaligus dianggap sebagai ulangan. Jenis umpan yang digunakan sama yaitu ikan tembang (Sardinella fimbriata) dengan cara pemasangan seperti disajikan pada Gambar 3.

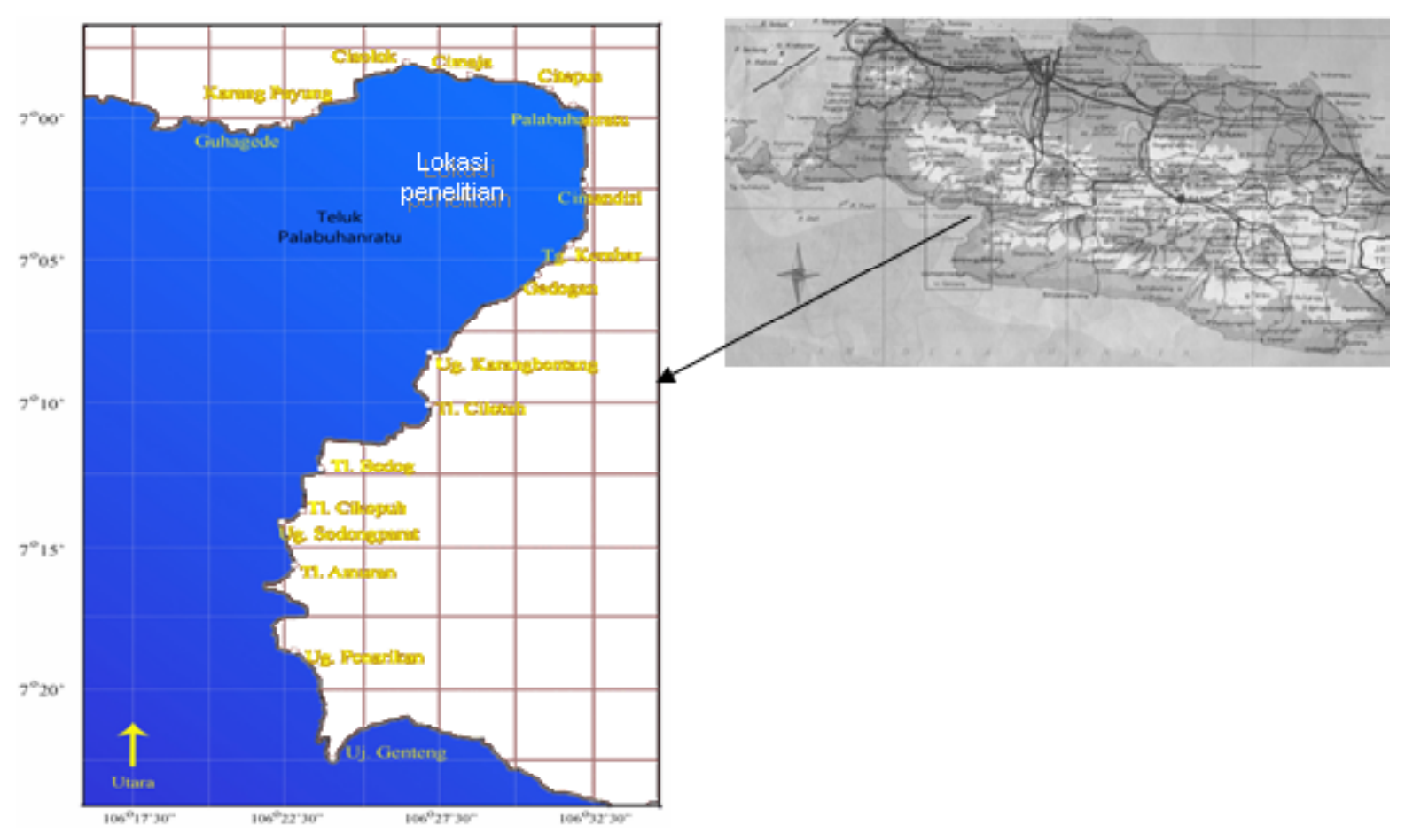

Gambar 1. Peta lokasi uji coba penangkapan vertikal longline di Pelabuhanratu. 
Gambar 2. Desain rawai ikan layur vertikal a) dengan mata pancing tunggal dan b) dengan mata pancing
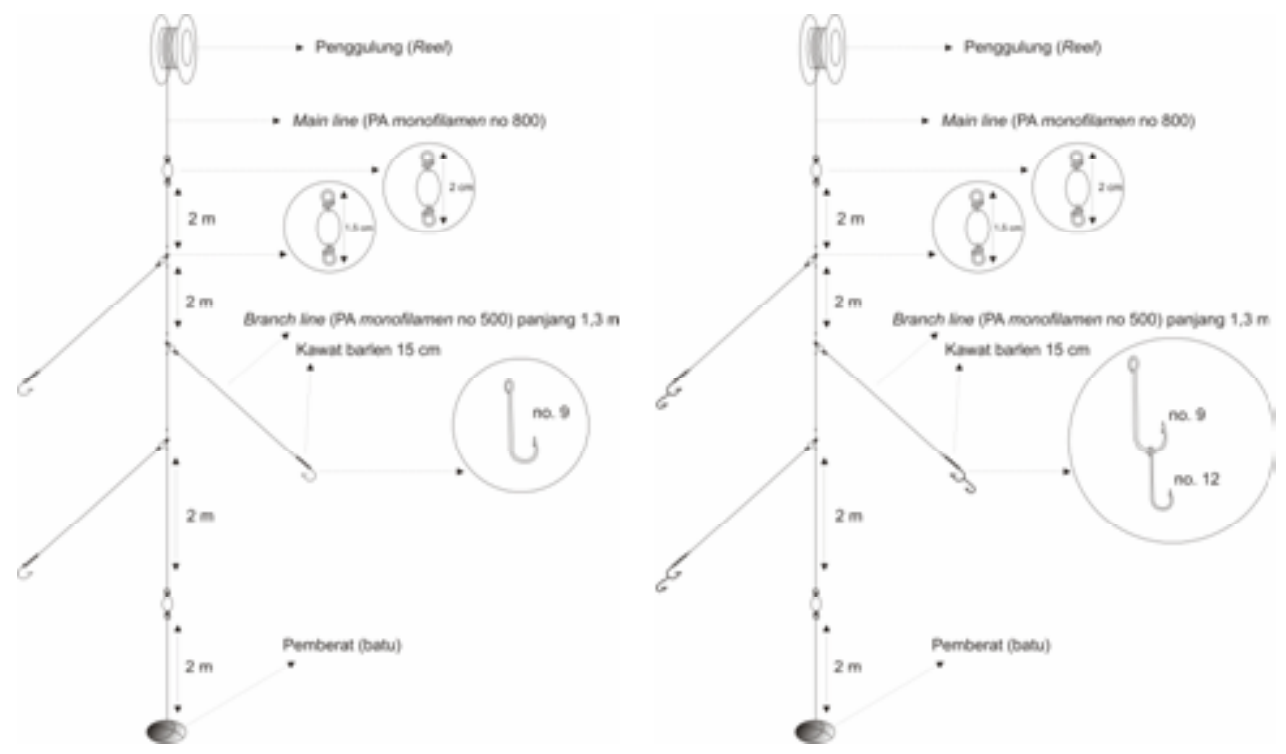
ganda.
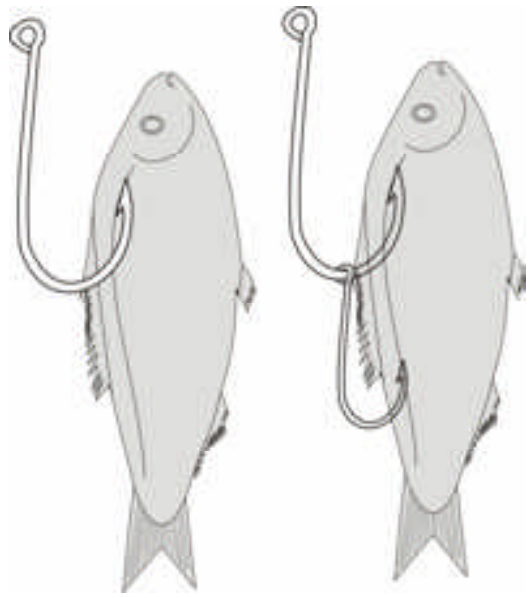

Gambar 3. Pemasangan umpan pada mata pancing tunggal dan ganda

\section{Analisis Data}

Jenis data yang dikumpulkan adalah komposisi jenis, ukuran ikan (panjang dan bobot) yang tertangkap oleh kedua jenis rawai. Rata-rata jumlah ikan layur yang tertangkap oleh kedua tipe rawai akan diuji beda nyata dengan analisis non parametrik, uji peringkat bertanda Wilcoxon. Namun sebelum uji ini diaplikasikan diuji terlebih dahulu kenormalan data dengan uji Kolmogorov-Smirnov (Harinaldi, 2005).

\section{HASIL DAN BAHASAN}

Penelitian ini dilaksanakan dalam 4 kali trip yang berlangsung selama 4 hari. Daerah penangkapan yang dipilih yaitu perairan Tunjangan yang terletak dekat dengan muara Sungai Cimandiri. Pengoperasian rawai dimulai dengan pemasangan umpan pada mata pancing, masing-masing mata pancing pada kedua unit rawai diberi umpan. Setelah itu kedua unit rawai diturunkan pada sisi perahu secara bersamaan dan dibiarkan selama 30 menit. Setelah 30 menit kedua unit rawai diangkat secara bersamaan ke atas perahu. Ikan hasil tangkapan dilepaskan dari mata pancing dan dipisahkan antara hasil tangkapan rawai dengan mata pancing tunggal dengan rawai dengan mata pancing ganda. Pada saat dilepaskan dari mata pancing dilihat juga cara ikan terkait mata pancing khususnya pada rawai dengan mata pancing ganda.

Hasil tangkapan yang didapatkan yaitu 94 ekor ikan dengan bobot total $51,09 \mathrm{~kg}$. Komposisi hasil tangkapan adalah ikan layur jenis meleu (Trichiurus haumela) 59 ekor, layur jenis bedog (Trichiurus savala) 22 ekor, dan hasil tangkapan sampingan yaitu geulang ruyu (Gempylus serpens) 11 ekor dan buntal (Diodon 
hystrix) 2 ekor, hal ini dapat dilihat pada Gambar 4. Ikan layur jenis Trichiurus haumela paling banyak tertangkap diduga karena lokasi penelitian memang daerah penangkapan ikan layur jenis Trichiurus haumela. Dari Gambar 5 dapat dilihat bahwa jumlah ikan layur yang tertangkap dengan rawai tegak yang menggunakan mata pancing ganda lebih banyak yaitu sekitar 51 ekor yang terdiri atas layur bedog 16 ekor dan jenis meleu 35 ekor, hasil tangkapan sampingannya yaitu ikan geulang ruyu 7 ekor dan buntal 1 ekor. Sedangkan jumlah ikan layur yang tertangkap dengan rawai tegak yang menggunakan mata pancing tunggal 30 ekor yang terdiri atas ikan layur jenis bedog 6 ekor dan 24 ekor layur jenis meleu, serta hasil tangkapan sampingan yeng terdiri atas geulang ruyu 4 ekor dan buntal 1 ekor. Data hasil tangkapan selengkapnya dapat dilihat pada Lampiran 1.

Dari Gambar 6 terlihat bahwa sebaran panjang ikan layur hasil tangkapan yang diperoleh kedua jenis rawai tidak terlalu berbeda. Jumlah hasil tangkapan yang tertinggi pada kedua jenis rawai berada pada kisaran yang sama yaitu 80-84 cm dengan jumlah 15 ekor untuk rawai tegak yang menggunakan mata pancing tunggal dan 16 ekor pada rawai tegak yang menggunakan mata pancing ganda. Hal ini diduga karena kedua unit rawai dioperasikan bersamaan dan di tempat yang sama di mana terdapat kelompok ikan layur yang memiliki ukuran yang hampir seragam.

Ukuran ikan layur hasil tangkapan yang didapatkan rawai yang menggunakan mata pancing ganda tidak jauh berbeda dengan hasil tangkapan rawai bermata pancing tunggal. Ikan layur yang tertangkap memiliki ukuran yang layak konsumsi sehingga penggunaan mata pancing ganda dapat diterapkan pada perikanan rawai ikan layur khususnya di Pelabuhanratu.
Sebelum data hasil tangkapan ikan layur pada kedua jenis rawai dianalisis untuk dapat dilihat perbandingannya, data tersebut diuji terlebih dahulu kenormalan datanya. Setelah diuji kenormalan data dengan menggunakan uji Kolmogorov-Smirnov dapat diketahui bahwa data hasil tangkapan rawai dengan menggunakan mata pancing tunggal dan yang menggunakan mata pancing ganda tidak menyebar normal, karena memiliki nilai taraf signifikan $<0,05$ (Sulaiman, 2004). Data hasil tangkapan rawai dengan mata pancing tunggal mempunyai nilai Asymp. Signifikan 0,028 sedangkan data hasil tangkapan rawai dengan mata pancing ganda mempunyai nilai Asymp. signifikan 0,016.

Karena data tidak menyebar normal analisis yang digunakan yaitu analisis non parametrik dengan uji pangkat bertanda Wilcoxon. Hasil yang diperoleh melalui uji bertanda Wilcoxon didapatkan nilai $\mathrm{W}_{+}$ sebesar 57,5 lebih kecil dari nilai W sebesar 152 pada 30 kali ulangan atau pasangan dan taraf nyata 0,05 (nilai kritis bagi uji pangkat bertanda Wilcoxon) sehingga hipotesis $\mathrm{H}_{0}$ dapat ditolak. Dari hasil uji ini dapat dikatakan bahwa rawai dengan mata pancing ganda memberikan hasil tangkapan ikan layur yang lebih baik dibandingkan dengan rawai yang menggunakan mata pancing tunggal dan terdapat perbedaan yang nyata pada kedua unit rawai dengan selang kepercayaan 95\% (Harinaldi, 2005).

Pada rawai yang menggunakan mata pancing ganda terdapat tiga cara ikan terkait mata pancing, yang pertama mulut ikan terkait pada mata pancing utama (mata pancing dengan No.9), yang kedua mulut ikan terkait pada mata pancing tambahan (mata pancing dengan No.12) dan yang terakhir mulut ikan terkait pada kedua mata pancing.

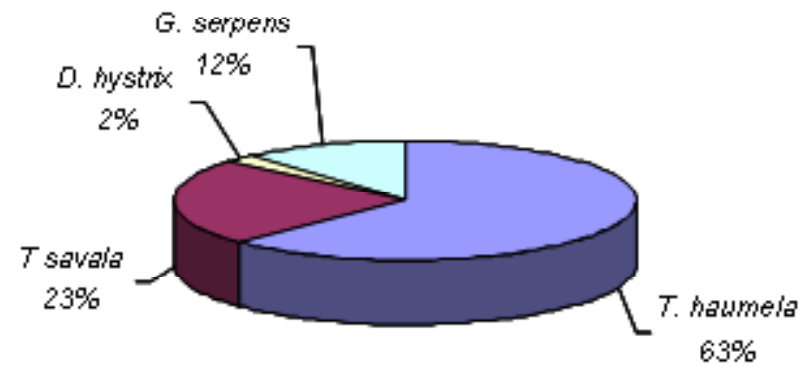

Gambar 4. Komposisi hasil tangkapan rawai tegak. 


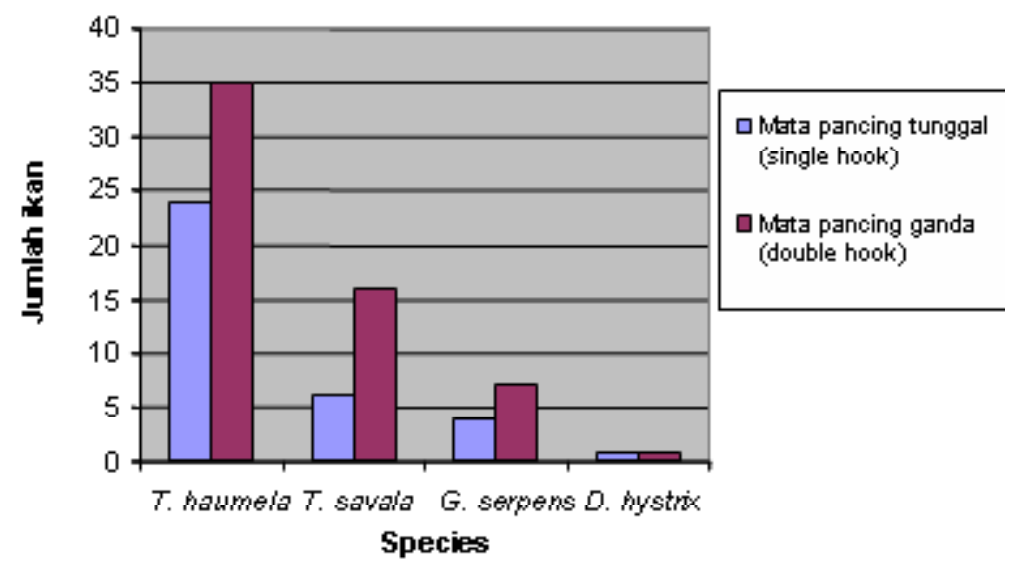

Gambar 5. Komposisi hasil tangkapan rawai tegak berdasarkan pada tipe mata pancing.

Gambar 6. Sebaran ukuran panjang ikan layur berdasarkan pada tipe mata pancing.

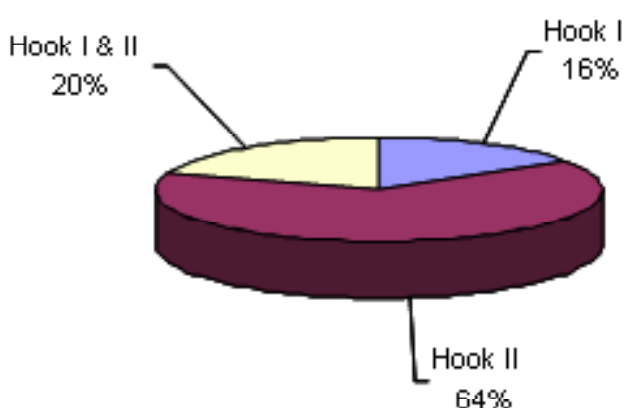

Gambar 7. Persentase ikan yang tertangkap oleh mata pancing ganda berdasarkan pada posisi mata pancing.

Dari data yang didapatkan pada saat penelitian, ikan layur yang tertangkap lebih banyak terkait pada mata pancing tambahan dibandingkan yang tertangkap pada mata pancing utama atau pada kedua mata pancing. Pada Gambar 7 dapat dilihat jumlah ikan yang terkait pada mata pancing tambahan 33 ekor jauh lebih banyak dibandingkan yang terkait pada mata pancing utama yaitu 10 ekor dan yang terkait pada kedua mata pancing 8 ekor. Hal ini disebabkan cara berenang ikan layur yang hampir vertikal dengan posisi kepala di atas (Masuda et al., 1975) sehingga bagian umpan yang lebih sering digigit atau dimakan adalah bagian umpan yang bawah di mana terdapat mata pancing tambahan (mata pancing No.12). 


\section{KESIMPULAN}

Hasil tangkapan ikan layur yang diperoleh dari rawai tegak yang menggunakan mata pancing ganda lebih banyak dari hasil tangkapan rawai tegak yang menggunakan mata pancing tunggal sehingga rawai dengan mata pancing ganda dapat digunakan oleh nelayan untuk meningkatkan hasil tangkapannya.

\section{PERSANTUNAN}

Tulisan ini merupakan kontribusi dari kegiatan riset hasil pengaruh perbedaan penggunaan bentuk mata pancing terhadap hasil tangkapan layur (Trichiurus sp.) di Pelabuhanratu, Jawa Barat, tahun 2008.

\section{DAFTAR PUSTAKA}

Budiman, I. 2006. Teknologi penangkapan ikan dan pengembangan usaha perikanan tenggiri di Kabupaten Belitung: Suatu pendekatan sistem bisnis perikanan. Tesis (tidak dipublikasikan). Program Pascasarjana. Institut Pertanian Bogor. Bogor. 72-78.

Direktorat Jendral Perikanan. 1998. Buku Pedoman Pengenalan Sumber Daya Perikanan Laut. Bagian I (Jenis-Jenis Ikan Ekonomis Penting). Jakarta. Departemen Pertanian.
Harinaldi. 2005. Prinsip-Prinsip Statistik untuk Teknik dan Sains. Jakarta. Erlangga. 230-233.

Masuda, H., C. Araga, \& T. Yoshino. 1975. Coastal Fishes of Southern Japan. Tokai University Press. Shuijuku. Tokyo. Japan. 80 pp.

Pelabuhan Perikanan Nusantara Pelabuhanratu. 2006. Data Statistika Perikanan Tahun 2005. Pelabuhan Perikanan Nusantara Pelabuhanratu. Sukabumi.

Sadhori, S. 1984. Teknik Penangkapan Ikan. Bandung. Angkasa.

Sasmita, V. S. 1995. Pendugaan potensi dan fluktuasi musim penangkapan sumber daya layur (Trichiurus sp.) di perairan Teluk Pelabuhanratu, Kabupaten Sukabumi, Jawa Barat. Skripsi (tidak dipublikasikan). Program Sarjana. Program Studi IImu Kelautan. Fakultas Perikanan dan IImu Kelautan. Institut Pertanian Bogor. Bogor.

Sulaiman, W. 2004. Analisis Regresi Menggunakan SPSS Contoh Kasus dan Pemecahannya. Yogyakarta. Andi. 32-34. 
Lampiran 1. Data hasil tangkapan ikan berdasarkan pada ulangan

\begin{tabular}{|c|c|c|c|c|c|c|c|}
\hline \multicolumn{4}{|c|}{ Rawai I } & \multicolumn{4}{|c|}{ Rawai II } \\
\hline No. & Spesies & $\begin{array}{c}\text { Bobot } \\
(\mathrm{g})\end{array}$ & $\begin{array}{c}\text { Panjang } \\
\text { (cm) }\end{array}$ & Spesies & $\begin{array}{l}\text { Bobot } \\
(\mathrm{g})\end{array}$ & $\begin{array}{c}\text { Panjang } \\
\text { (cm) }\end{array}$ & $\begin{array}{c}\text { Posisi pada rawai } \\
\text { II }\end{array}$ \\
\hline \multirow[t]{2}{*}{1.} & G. serpens & 550 & 72 & T. savala & 500 & 70 & II \\
\hline & & & & T. savala & 600 & 72 & II \\
\hline 2. & & & & T. savala & 700 & 80 & II \\
\hline \multirow[t]{2}{*}{3.} & & & & T. savala & 480 & 65 & II \\
\hline & & & & T. savala & 530 & 70 & II \\
\hline 4. & & & & T. savala & 620 & 70 & 1 \\
\hline 5. & & & & T. savala & 500 & 70 & II \\
\hline \multirow{6}{*}{6.} & T. haumela & 750 & 90 & T. savala & 800 & 80 & | dan II \\
\hline & T. haumela & 550 & 80 & T. savala & 850 & 84 & II \\
\hline & T. savala & 550 & 75 & T. haumela & 500 & 75 & II \\
\hline & T. haumela & 500 & 72 & T. savala & 350 & 62 & II \\
\hline & & & & T. haumela & 400 & 60 & II \\
\hline & & & & G. serpens & 850 & 82 & | dan || \\
\hline \multirow[t]{3}{*}{7.} & T. savala & 650 & 82 & G. serpens & 700 & 80 & II \\
\hline & T. haumela & 500 & 75 & & & & \\
\hline & T. savala & 1.000 & 85 & & & & \\
\hline 8. & T. haumela & 550 & 90 & T. savala & 550 & 73 & | dan || \\
\hline \multirow[t]{2}{*}{9.} & T. savala & 850 & 82 & T. haumela & 500 & 72 & II \\
\hline & & & & T. haumela & 470 & 78 & 1 \\
\hline \multirow[t]{5}{*}{10.} & T. haumela & 630 & 83 & T. haumela & 400 & 82 & II \\
\hline & T. haumela & 400 & 75 & T. haumela & 330 & 73 & 1 \\
\hline & & & & T. haumela & 500 & 85 & II \\
\hline & & & & T. savala & 970 & 93 & | dan || \\
\hline & & & & T. haumela & 450 & 78 & I \\
\hline \multirow[t]{5}{*}{11.} & T. savala & 700 & 85 & T. savala & 400 & 64 & II \\
\hline & T. haumela & 430 & 80 & T. haumela & 500 & 83 & | dan || \\
\hline & & & & T. haumela & 380 & 73 & II \\
\hline & & & & T. haumela & 380 & 73 & II \\
\hline & & & & T. haumela & 370 & 73 & 1 \\
\hline 12. & G. serpens & 870 & 85 & & & & \\
\hline 13. & T. haumela & 550 & 87 & G. serpens & 900 & 82 & | dan || \\
\hline \multirow[t]{2}{*}{14.} & & & & T. haumela & 570 & 82 & II \\
\hline & & & & G. serpens & 550 & 75 & | dan || \\
\hline \multirow[t]{2}{*}{15.} & T. savala & 1.100 & 95 & D. histrix & 1.300 & 60 & II \\
\hline & & & & T. haumela & 1200 & 92 & II \\
\hline \multirow[t]{2}{*}{16.} & & & & G. serpens & 350 & 65 & | dan || \\
\hline & & & & T. haumela & 420 & 75 & I \\
\hline 17. & & & & T. haumela & 300 & 70 & II \\
\hline 18. & G. serpens & 400 & 60 & T. savala & 400 & 87 & II \\
\hline 19. & G. serpens & 520 & 67 & G. serpens & 720 & 80 & 1 \\
\hline \multirow[t]{2}{*}{20.} & T. haumela & 400 & 80 & T. haumela & 450 & 80 & II \\
\hline & & & & T. haumela & 520 & 75 & II \\
\hline 21. & T. haumela & 600 & 70 & T. savala & 400 & 70 & II \\
\hline 22. & T. haumela & 480 & 82 & T. haumela & 450 & 90 & II \\
\hline 23. & & & & T. haumela & 600 & 90 & | dan || \\
\hline \multirow[t]{3}{*}{24.} & T. haumela & 350 & 80 & T. haumela & 450 & 82 & II \\
\hline & T. haumela & 450 & 80 & T. haumela & 450 & 75 & 1 \\
\hline & T. haumela & 330 & 74 & & & & \\
\hline \multirow[t]{2}{*}{25.} & T. haumela & 480 & 80 & T. haumela & 380 & 73 & II \\
\hline & & & & G. serpens & 550 & 74 & II \\
\hline
\end{tabular}


Lampiran 1. Lanjutan

\begin{tabular}{|c|c|c|c|c|c|c|c|}
\hline \multicolumn{4}{|c|}{ Rawai I } & \multicolumn{4}{|c|}{ Rawai II } \\
\hline No. & Spesies & $\begin{array}{c}\text { Bobot } \\
\text { (g) }\end{array}$ & $\begin{array}{l}\text { Panjang } \\
\text { (cm) }\end{array}$ & Spesies & $\begin{array}{l}\text { Bobot } \\
\text { (g) }\end{array}$ & $\begin{array}{l}\text { Panjang } \\
\text { (cm) }\end{array}$ & $\begin{array}{c}\text { Posisi pada rawai } \\
\text { II }\end{array}$ \\
\hline \multirow[t]{5}{*}{26.} & T. haumela & 450 & 80 & T. haumela & 400 & 75 & I dan II \\
\hline & T. haumela & 430 & 80 & & & & \\
\hline & T. haumela & 450 & 82 & & & & \\
\hline & T. haumela & 600 & 85 & & & & \\
\hline & T. haumela & 500 & 85 & & & & \\
\hline \multirow[t]{4}{*}{27.} & T. haumela & 520 & 75 & T. haumela & 500 & 80 & II \\
\hline & T. haumela & 380 & 80 & T. haumela & 450 & 75 & I dan II \\
\hline & & & & T. haumela & 500 & 82 & II \\
\hline & & & & T. haumela & 450 & 80 & II \\
\hline \multirow[t]{2}{*}{28.} & T. haumela & 500 & 80 & T. haumela & 620 & 80 & II \\
\hline & & & & T. haumela & 350 & 72 & I dan II \\
\hline \multirow[t]{4}{*}{29.} & D. histrix & 800 & 35 & T. haumela & 500 & 80 & II \\
\hline & & & & T. haumela & 520 & 90 & I dan II \\
\hline & & & & T. haumela & 400 & 80 & II \\
\hline & & & & T. haumela & 350 & 80 & I dan II \\
\hline \multirow[t]{2}{*}{30.} & & & & T. haumela & 400 & 77 & II \\
\hline & & & & T. haumela & 350 & 80 & I dan II \\
\hline
\end{tabular}

